Gut, 1983, 24, 67-72

\title{
Vitamin D and bone mineral content after intestinal bypass operation for obesity
}

\author{
H RICKERS, ${ }^{*}$ C CHRISTIANSEN, I BALSLEV, H FOLTVED, \\ $P$ R ØDBRO, and M S CHRISTENSEN
}

From the Department of Clinical Physiology and Surgical Department A, Aalborg Hospital, DK-9100 Aalborg, and the Department of Clinical Chemistry, Glostrup Hospital, University of Copenhagen, DK-2600 Glostrup, Denmark

SUMMARY Twenty-three obese subjects who had undergone intestinal bypass operation (end-to-side jejunostomy) were studied with respect to vitamin D and other indices of calcium metabolism. Group 1 (11 patients) was examined before and one year after operation. Group 2 (12 patients, bypass operated two to seven years earlier) was investigated twice with an interval of one year. The two groups were comparable. Bone mineral content and alkaline phosphatases were unchanged during the study in both groups. Bone phosphorus/hydroxyproline ratio was high postoperatively indicating a high degree of bone mineralisation. Serum calcium declined rapidly in group 1 to a constant level, which was maintained in group 2 . The serum levels of iPTH and $1,25(\mathrm{OH})_{2} \mathrm{D}$ did not change within each group, but combining the two groups demonstrated an increase/decrease in iPTH/1,25(OH $)_{2} \mathrm{D}$ over the years. The findings suggest that factors other than $1,25(\mathrm{OH})_{2} \mathrm{D}$ and $\mathrm{iPTH}$ are involved in calcium metabolism in such patients. The findings do not justify routine administration to such patients of high potency vitamin $D$ derivatives, f.ex. $1 \alpha-\mathrm{OH}-\mathrm{D}_{3}$.

Intestinal bypass operation has been widely practised within the last decade as radical treatment of extreme obesity. Many late complications of this operation have been reported, among these metabolic bone disease. The induced malabsorption may involve calcium and vitamin $\mathrm{D},{ }^{12}$ and other disturbances in vitamin $\mathrm{D}$ metabolism may appear. ${ }^{3-5}$ Whether this leads to bone disease from loss of bone mineral content seems not to be clear; conflicting results in the measurements of bone mineral content appear in several reports. ${ }^{12467}$ In some studies low serum values of the metabolite 25 -hydroxyvitamin D (25-OH-D) were found postoperatively, which might suggest that osteomalacia had developed. ${ }^{2-5}$ The serum concentration of 25-OH-D is, however, sensitive to oral intake of vitamin $D$, shows considerable seasonal variation, and, furthermore, this metabolite is but a precursor to the active

\footnotetext{
* Address for correspondence: Dr H Rickers, Department of Clinical Physiology. Aalborg Hospital, DK-9100 Aalborg, Denmark.

Received for publication 1 March 1982
}

metabolite. The active metabolite is believed to be the further hydroxylated 1,25-dihydroxy-vitamin D $\left(1,25(\mathrm{OH})_{2} \mathrm{D}\right)$, which recently became measurable. Studies concerning vitamin D metabolism in such patients have till now been cross-sectional. ${ }^{2-5}$

We have performed a longitudinal study of vitamin $\mathrm{D}$ metabolism in these patients and compared these findings with results from simultanous measurements of bone- and biochemical indices of calcium metabolites.

\section{Methods}

\section{PATIENTS}

Twenty-three obese subjects who consecutively had undergone intestinal bypass operation in 1971-78 at the Surgical Department A, Aalborg Hospital, were studied. End-to-side jejunoileostomy with preservation of $36 \mathrm{~cm}$ jejunum and $12 \mathrm{~cm}$ ileum had been carried out in all patients. The entire group (two men and 21 women) was divided into two subgroups. 
Group $1(\mathrm{n}=11)$

This group was examined before operation $\left(\mathrm{t}_{0}\right)$, six and 12 months after operation $\left(t_{1}\right.$ and $\left.t_{2}\right)$, respectively.

\section{Group $2(\mathrm{n}=12)$}

Patients in this group, who had been bypassoperated two to seven years (mean 3.5 years) earlier, were investigated twice with an interval of 12 months $\left(t_{a}\right.$ and $\left.t_{b}\right)$.

The two groups did not differ significantly as regards age, preoperative weight, or weight loss postoperatively. Mean and range age for group 1 were: 33 years (range 22-41 years), for group 2: 34 years (range 25-49 years). Mean and range percental overweight for group 1 were: at $\mathrm{t}_{0}: 114 \%$ (range $82-159 \%$ ), at $\mathrm{t}_{2}: 38 \%$ (range $13-72 \%$ ); for group 2: at $\mathrm{t}_{\mathrm{a}}: 48 \%$ (range $32-82 \%$ ), and at $\mathrm{t}_{\mathrm{b}}: 43 \%$ (range 2-95\%).

During the period of observation no therapeutic calcium or vitamin D supply was given. In some patients substitution with magnesium and potassium was necessary.

\section{BIOCHEMISTRY}

Blood was collected in the morning after an overnight fast. Serum calcium $(2 \cdot 50 \pm 0 \cdot 10 \mathrm{mmol} / \mathrm{l})$, phosphate $(1 \cdot 17 \pm 0.19 \mathrm{mmol} / \mathrm{l})$, alkaline phosphatases $(2.06 \pm 0.19 \log \mathrm{U} / \mathrm{l})$, and protein $(76 \pm 4 \mathrm{~g} / \mathrm{l})$ were measured on a SMA $12 / 60$ autoanalyser. Serum magnesium $(0 \cdot 85 \pm 0.10 \mathrm{mmol} / \mathrm{l})$ was measured by atomic absorption, and serum albumin $(43 \pm 4 \mathrm{~g} / \mathrm{l})$ by immunoprecipitation. The values in parentheses are normal mean \pm 1 standard deviation. All measurements were made in duplicate and serum calcium was corrected to a constant serum albumin level.

Serum concentration of immunoreactive parathyroid hormone (iPTH) was measured by radioimmunoassay as described in detail elsewhere. ${ }^{8}$ Normal range is $30-105 \mathrm{pg} / \mathrm{ml}$.

\section{Vitamin $D$ measurements}

Blood was stored at $-20^{\circ} \mathrm{C}$ for simultaneous measurements. Serum concentrations of 25-OH-D and $1,25(\mathrm{OH})_{2} \mathrm{D}$ were measured by previously described methods. ${ }^{9}$ Normal mean \pm 1 standard deviation is $26.4 \pm 10.9 \mathrm{ng} / \mathrm{ml}$ and $28.0 \pm 10.9 \mathrm{pg} / \mathrm{ml}$, respectively; intraindividual assay variation is about $8 \%$. The methods involve specific extraction procedures followed by chromatography including known internal standards to determine recovery of each metabolite. The metabolites were finally measured by competitive binding assay $(1,25-$ $\left.(\mathrm{OH})_{2} \mathrm{D}\right)$ or UV detection (25-OH-D).

\section{BONE MEASUREMENTS}

\section{Bone mineral content}

This was measured by two-dimensional scanning photon absorptiometry $\left({ }^{125} \mathrm{I}\right)$ on the distal part of the forearm and calculated as the mean of 12 scans (six on each arm). This method has a long-term reproducibility of $1.2 \%$ in normal subjects, ${ }^{10}$ and values of bone mineral content measured on the forearm correlate well with bone mineral on other locations and with total body calcium. As a fat layer on the forearm gives systematic underestimation of bone mineral content, a 'fat correction' 11 was made for each value. Finally, bone mineral content values were expressed in percentage of sex and age matched normal mean, and were compared with published reference values.

\section{Degree of bone mineralisation}

This was estimated from the phosphorus/hydroxyproline ratio (P/Hypro) measured on small bone biopsies from the iliac crest. ${ }^{12}$ Biopsies were obtained from four patients in group 1 (at $t_{0}$ and $t_{2}$ ) and 11 patients in group 2 (at $\left.t_{b}\right)$. Values were expressed in percentage of corresponding normal mean. P/Hypro correlates with the amount of bone volume as determined by histomorphometry in normal subjects ${ }^{13}$ and in patients with renal osteodystrophy (Tougaard, personal communication).

\section{STATISTICS}

For statistical analyses Wilcoxon's rank sum test was used for paired data and the Mann-Whitney rank sum test for unpaired data. Correlations were analysed with Spearman's rank correlation.

\section{Results}

The results are shown in Tables 1 and 2 . In group 1 mean serum values of calcium, magnesium, total protein, and albumin fell significantly after operation. In group 2 there were no significant changes during 12 months' observation.

Mean bone mineral content was normal in both groups and remained unchanged throughout the study. The individual bone mineral changes did not correlate with any of the biochemical parameters.

Mean P/Hypro values at $t_{0}$ and $t_{2}$ in four patients in group 1 were $106.0 \% \pm 4.2 \%$ (SD) and $111.8 \% \pm 8.3 \%$ (SD), respectively. The rise was not significant. In 11 patients in group $2 \mathrm{P} /$ Hypro values (mean $110.6 \% \pm 6.2 \%$ (SD)) were significantly higher $(\mathrm{p}<0.001)$ than in normal subjects $(100.0 \% \pm 7.1 \% \mathrm{CV})$ at $t_{b}(54$ months after operation).

The salient features in vitamin D measurements 
Table 1 Serum and bone mineral content values (mean $\pm S D$ ) in 11 (group 1) patients at time of investigation

\begin{tabular}{|c|c|c|c|}
\hline & \multicolumn{2}{|l|}{ Operation } & \multirow[b]{2}{*}{$\begin{array}{l}\text { Significance of } \\
\text { difference }\end{array}$} \\
\hline & $\begin{array}{l}\text { Before } \\
t_{0}\end{array}$ & $\begin{array}{l}12 \text { months after } \\
t_{2}\end{array}$ & \\
\hline \multicolumn{4}{|l|}{ Serum } \\
\hline \multirow[t]{2}{*}{$25-\mathrm{OH}-\mathrm{D}(\mathrm{ng} / \mathrm{ml})$} & 13.9 & $5 \cdot 9$ & \\
\hline & $10 \cdot 6-32 \cdot 4^{*}$ & $2 \cdot 6-27 \cdot 1^{*}$ & $\mathrm{p}<0.01$ \\
\hline $1,25(\mathrm{OH})_{2} \mathrm{D}(\mathrm{pg} / \mathrm{ml})$ & $30 \cdot 9 \pm 11 \cdot 1$ & $26 \cdot 9 \pm 8 \cdot 0$ & NS \\
\hline \multirow[t]{2}{*}{ iPTH $(\mathrm{pg} / \mathrm{ml})$} & 16 & 20 & \\
\hline & $2-64^{*}$ & $6-200^{*}$ & NS \\
\hline Calcium $(\mathrm{mmol} / \mathrm{l}) \dagger$ & $2 \cdot 45 \pm 0 \cdot 10$ & $2 \cdot 26 \pm 0 \cdot 14$ & $\mathrm{p}<0.001$ \\
\hline Phosphate $(\mathrm{mmol} / \mathrm{l}) \dagger$ & $1 \cdot 03 \pm 0 \cdot 17$ & $1 \cdot 03 \pm 0 \cdot 16$ & NS \\
\hline Alkaline phosphatase $(\log \mathrm{U} / \mathrm{l})$ & $2 \cdot 10 \pm 0 \cdot 16$ & $2 \cdot 15 \pm 0 \cdot 17$ & NS \\
\hline Magnesium $(\mathrm{mmol} / \mathrm{l}) \dagger$ & $0 \cdot 80 \pm 0 \cdot 05$ & $0 \cdot 65 \pm 0 \cdot 10$ & $\mathrm{p}<0.001$ \\
\hline Albumin $(\mathrm{g} / \mathrm{l})$ & $41 \pm 4$ & $33 \pm 4$ & $\mathrm{p}<0.001$ \\
\hline Protein $(g / 1)$ & $74 \pm 3$ & $62 \pm 4$ & $\mathrm{p}<0.001$ \\
\hline \multicolumn{4}{|l|}{ Bone } \\
\hline BMC ( $\%$ of sex and age matched normal) & $102 \cdot 6 \pm 10 \cdot 5$ & $100 \cdot 8 \pm 9 \cdot 7$ & NS \\
\hline
\end{tabular}

* Median value and range.

† Unit conversion factors: calcium: $1 \mathrm{mmol} / \mathrm{l}=4.02 \mathrm{mg} / 100 \mathrm{ml}$; phosphate: $1 \mathrm{mmol} / \mathrm{l}=3.1 \mathrm{mg} / 100 \mathrm{ml} ;$ magnesium: $1 \mathrm{mmol} / \mathrm{l}=2.43$ $\mathrm{mg} / 100 \mathrm{ml}$.

were, for group 1 , a significant fall in $25-\mathrm{OH}-\mathrm{D}$, but unchanged $1,25(\mathrm{OH})_{2} \mathrm{D}$ values within the first 12 months postoperatively. In group 2 (two to seven years postoperatively), on the contrary, almost normal 25-OH-D values, corresponding to pretreatment values in group 1 , were found, while $1,25(\mathrm{OH})_{2} \mathrm{D}$ values were subnormal $(\mathrm{p}<0 \cdot 001)$. The values did not differ in patients with $(n=7)$ and without $(n=5)$ intake of ordinary vitamin tablets before investigation.

As for serum iPTH, there were no significant changes in group 1, but a small, but significant, rise in group 2 during one year of observation.

The findings of serum calcium, $1,25(\mathrm{OH})_{2} \mathrm{D}$ and iPTH are summarised for both groups in Fig. 1, where we combined the results by interextrapolation: the salient figures are a rapid decline in serum calcium to a stable subnormal level; a change between groups in iPTH (rise from group 1 to group 2 ), and a significant fall between groups in $1,25(\mathrm{OH})_{2} \mathrm{D}$.

Figure 2 demonstrates the lack of changes for serum alkaline phosphatases and bone mineral content within and between groups.

Table 2 Serum and bone minera! content values (mean $\pm S D)$ in 12 (group 2) patients at time of investigation

\begin{tabular}{|c|c|c|c|}
\hline & $\begin{array}{l}t_{a}=2-7 \text { years } \\
\text { after operation }\end{array}$ & $\begin{array}{l}t_{b}=t_{a}+ \\
12 \text { months }\end{array}$ & $\begin{array}{l}\text { Significance of } \\
\text { difference }\end{array}$ \\
\hline \multicolumn{4}{|l|}{ Serum } \\
\hline $25-\mathrm{OH}-\mathrm{D}(\mathrm{ng} / \mathrm{ml})$ & $\begin{array}{l}15 \cdot 5 \\
8 \cdot 3-46 \cdot 7^{*}\end{array}$ & $\begin{array}{l}12 \cdot 4 \\
2 \cdot 5-39 \cdot 1^{*}\end{array}$ & NS \\
\hline $1,25(\mathrm{OH})_{2} \mathrm{D}(\mathrm{pg} / \mathrm{ml})$ & $17 \cdot 7 \pm 4 \cdot 2$ & $16 \cdot 4 \pm 2 \cdot 8$ & NS \\
\hline $\mathrm{iPTH}(\mathrm{pg} / \mathrm{ml})$ & $\begin{array}{l}26 \\
8-110^{*}\end{array}$ & $\begin{array}{l}29 \\
14-126^{*}\end{array}$ & $\mathrm{p}<0.05$ \\
\hline Calcium $(\mathrm{mmol} / \mathrm{l}) \dagger$ & $2 \cdot 28 \pm 0.07 \dagger$ & $2 \cdot 26 \pm 0 \cdot 10 \dagger$ & NS \\
\hline Phosphate $(\mathrm{mmol} / \mathrm{l}) \dagger$ & $1 \cdot 10 \pm 0 \cdot 14$ & $0 \cdot 96 \pm 0 \cdot 15$ & $\mathrm{p}<0.05$ \\
\hline Alkaline phosphatase $(\log U / 1)$ & $2 \cdot 08 \pm 0 \cdot 18$ & $2 \cdot 06 \pm 0 \cdot 14$ & NS \\
\hline Magnesium $(\mathrm{mmol} / \mathrm{l}) \dagger$ & $0.73 \pm 0.08 \dagger$ & $0.70 \pm 0.06 \dagger$ & NS \\
\hline Albumin $(g / 1)$ & $37 \pm 3+$ & $39 \pm 3 \dagger$ & NS \\
\hline Protein $(\mathrm{g} / \mathrm{l})$ & $66 \pm 3+$ & $69 \pm 4^{*}$ & NS \\
\hline \multicolumn{4}{|l|}{ Bone } \\
\hline BMC (\% of sex and age matched normal) & $103 \cdot 9 \pm 9 \cdot 4$ & $103 \cdot 8 \pm 9 \cdot 0$ & NS \\
\hline
\end{tabular}

* Median value and range.

+ Unit conversion factors: calcium: $1 \mathrm{mmol} / 1=4.02 \mathrm{mg} / 100 \mathrm{ml}$; phosphate: $1 \mathrm{mmol} / \mathrm{l}=3.1 \mathrm{mg} / 100 \mathrm{ml}$; magnesium: $1 \mathrm{mmol} / \mathrm{l}=2.43$ $\mathrm{mg} / 100 \mathrm{ml}$. 
Fig. 1 Mean serum values of calcium, $1,25(\mathrm{OH})_{2} \mathrm{D}$ and $\mathrm{iPTH}$ in 23 bypass operated patients. Values in group 1 and group 2 (time since operation given as mean values) are combined by extrapolation (dashed lines). Calcium: $1 \mathrm{mmol} / \mathrm{l}=4.02 \mathrm{mg} /$ $100 \mathrm{ml}$.

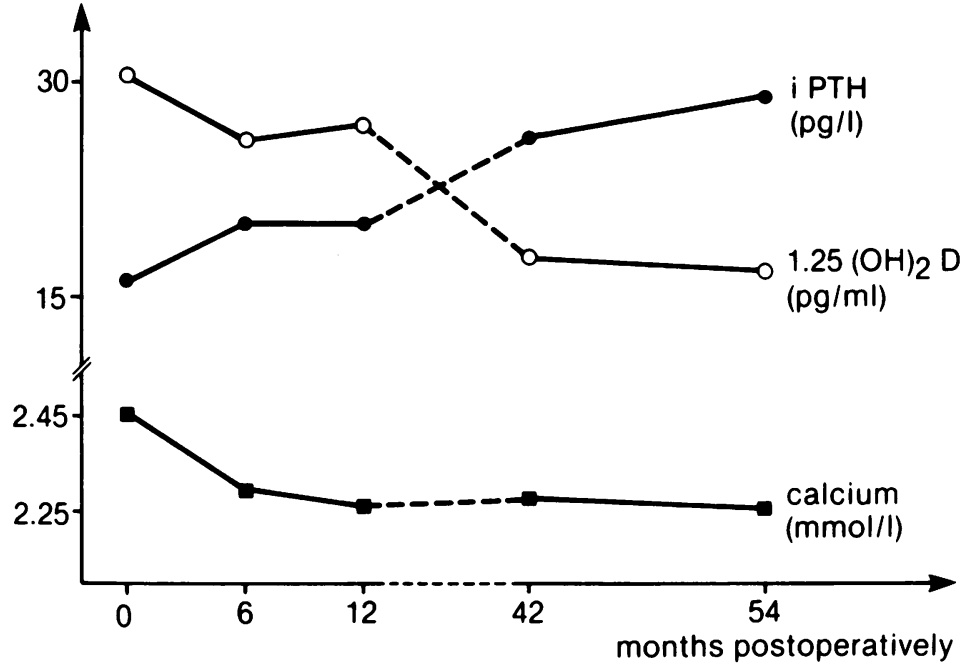

\section{Discussion}

No patient, in this study, had received therapeutic vitamin $\mathrm{D}$ or calcium supply during the study, but some subjects studied only postoperatively had taken ordinary multivitamin tablets (containing 400 IU vitamin $D_{3}$ ) after the operation until a minimum of four weeks before the trial. Apparently, this did not influence serum levels of 25-OH-D or $1,25(\mathrm{OH})_{2} \mathrm{D}$ and, as the two patients groups were comparable as regards age, sex distribution, surgical procedure, and postoperative weight loss, an extrapolation of the findings summarised in Fig. 1 seems allowable. Preoperatively, we found low levels of 25-OH-D in obese patients; this could be explained by scanty exposure to sunlight because of this immobilisation. Preoperative values of 1,25 $(\mathrm{OH})_{2} \mathrm{D}$, and serum iPTH were normal.
The biochemical findings postoperatively support the hypothesis of malabsorption also demonstrated in other patient series. ${ }^{267}$ In this study, however, serum calcium did not normalise with time. Postoperatively there was a fall in mean values of 25-OH-D during the first year. But later on (in the group studied two to seven years postoperatively) mean values rose significantly to preoperative figures. These findings are consistent with those of Teitelbaum et al. ${ }^{5} 25-\mathrm{OH}-\mathrm{D}$ is the major part of circulating vitamin D metabolites. Malabsorption with steatorrhoea would impair the absorption of vitamin $\mathrm{D}$, resulting in low serum values of $25-\mathrm{OH}$ D. To eliminate the well-known seasonal variation in serum 25-OH-D we designed the study in such a way that each patient was measured with one year's interval. All patients in group 2 entered the study in October, which can be looked upon as having an
Fig. 2 Mean values of serum alkaline phosphatases and bone mineral content in 23 bypass operated patients. Values in group 1 and group 2 are combined by extrapolation (dashed lines).

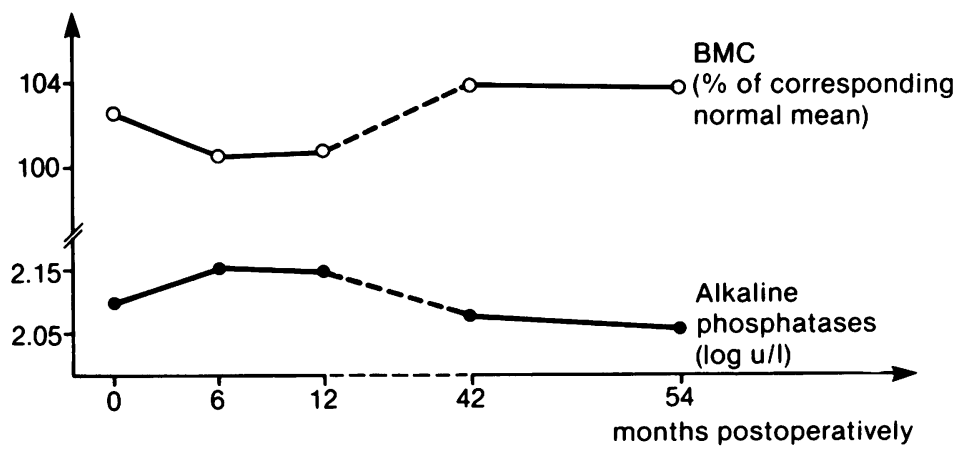


average serum $25-\mathrm{OH}-\mathrm{D}$ value. This would facilitate comparison between group 1 and group 2, as the patients in group 1 entered the study successively over one year (again resulting in a nearly average value of $25-\mathrm{OH}-\mathrm{D})$. In contrast with $25-\mathrm{OH}-\mathrm{D}$, serum $1,25(\mathrm{OH})_{2} \mathrm{D}$ values were normal in the first year postoperatively (group 1), while significantly decreased values were seen in group 2 with no change during the observation period of one year; this suggests that any possible impairment in vitamin D metabolism at this level progressed very slowly, if at all. The clinical importance of reduced $1,25(\mathrm{OH})_{2} \mathrm{D}$ is not clear. The fall in serum calcium early in the postoperative state is clearly not due to impairment in vitamin D metabolism, and the lack of correlation between serum calcium and serum $1,25(\mathrm{OH})_{2} \mathrm{D}$, later on indicates an alternative mechanism in the calcium malabsorption - possibly because of the shortened functioning intestine per se.

The question then arises whether the decreased calcium absorption leads to a negative calcium balance with loss of bone mineral. The calcium balance might be preserved at a lower level because of reduced urinary calcium output; the slight increase in serum iPTH supports this hypothesis. In other studies of similar patients ${ }^{2}$ urinary calcium output has been found to be low postoperatively. Our bone mineral content results did not indicate bone mineral loss in either of the groups during 12 months of observation and, comparing the two groups, up to eight years after observation. Though our groups were relatively small, the bone mineral content method used in this study has such a high precision that even small changes in this content during 12 months would have been detected. Though measured only on the forearm, bone mineral content here correlates well with total body calcium in normal subjects ${ }^{14}$ as well as in osteoporotic patients. ${ }^{15}$ Furthermore, low bone mineral content values have been demonstrated in other clinical conditions associated with metabolic bone disease. ${ }^{1617}$ Therefore, bone mineral content measured on the forearm, especially in longitudinal measurements, is a suitable method for estimating development of metabolic bone disease. As previously noted a correction of bone mineral content for fat on the forearm ${ }^{11}$ is mandatory when measuring on obese subjects - and a lack of such correction may explain low postoperative bone mineral values found in other studies. ${ }^{1256}$

Though it has been shown that $88 \%$ of the variation in bone mineral content in the forearm could be explained by the variation in amount of bone determined by histomorphometry, ${ }^{18}$ the present bone mineral results, obviously, do not exclude histologically defined osteomalacia as demonstrated in some reports. ${ }^{3}$ However, considering the findings of serum $1,25(\mathrm{OH})_{2} \mathrm{D}$, iPTH, and alkaline phosphatase it is unlikely that gross osteomalacia had developed in our patients and, if present, mild or moderate osteomalacia postoperatively may not necessarily lead to bone mineral loss and clinical bone symptoms. Provided that bone matrix is unaltered, our findings of high $\mathrm{P} /$ Hypro ratio postoperatively, moreover, indicate a high degree of mineralisation, which speaks against osteomalacia. ${ }^{12}$ Our patients do not differ from others as regards surgical procedure (Payne's type I) or degree of weight loss postoperatively (averaging $33 \%$ of preoperative weight).

The lack of changes in our longitudinal bone mineral content measurements, however, does not exclude a slight acceleration of physiological bone loss below the conventional level of statistical significance. This, in particular, would lead to poor prognostic implications later on for the younger females. Serial bone mineral content measurements for much longer periods by means of a highprecision method are needed further to elucidate this problem.

The study was supported by grants from the Danish Hospital Foundation for Medical Research, Region of Copenhagen, Faroe Islands and Greenland (J. no. $7 / 80)$

\section{References}

1 Danø P, Christiansen C. Calcium absorption and absence of bone decalcination following intestinal shunt operation for obesity. Scand J Gastroenterol 1978; 13: 81-5.

2 Hey H, Lund B, Sørensen OH, Lund B, Christensen MS. Impairment of vitamin D and bone metabolism in patients with bypass operation for obesity. Acta Med Scand 1979; 624: suppl: 73-8.

3 Compston JE, Horton LWL, Lakdler MF, et al. Bone disease after jejuno-ileal bypass for obesity. Lancet 1978; 2: $1-4$.

4 Parfitt AM, Miller MJ, Frame B, Villanueva AR, Rao DS, Oliver I, Thomson D. Metabolic bone disease after intestinal bypass for treatment of obesity. Ann Intern Med 1978; 89: 193-9.

5 Teitelbaum SL, Halverson JD, Bates M, Wise L, Haddad JG. Abnormalities of circulating 25-OHvitamin D after jejuno-ileal bypass for obesity. Ann Intern Med 1977; 86: 289-93.

6 Campbell JM, Hunt TK, Karam JH, Forsham PH. Jejunoileal bypass as a treatment of morbid obesity. Arch Intern Med 1977; 137: 602-10. 
7 Halverson JD, Wise L, Ballinger WF. Jejunoileal bypass for morbid obesity. A critical appraisal. Am J Med 1978; 64: 461-75.

8 Christensen MS. A sensitive radioimmunoassay of parathyroid hormone in human serum using a specific extraction procedure. Scand J Clin Lab Invest 1976; 36: 313-22.

9 Shepard RM, Horst RL, Jorgensen NA, DeLuca HF. Determination of vitamin $\mathrm{D}$ and its metabolites in plasma from normal and anephric man. Biochem $J$ 1979; 182: 55-69.

10 Christiansen C, Rødbro P. Long-term reproducibility of bone mineral content measurements. Scand J Clin Lab Invest 1977; 37: 321-3.

11 Rickers H, Balslev I, Foltved H, Rødbro P. Bone mineral content before and after intestinal bypass operation in obese patients. Acta Med Scand 1981; 209: 203-7.

12 Tougaard L. Knoglers mineraliseringsgrad bedømt ved knogle Phosphor/Hydroxyprolin ratio. Thesis. FADL's forlag Kopenhagen, 1979.

13 Tougaard L, Melsen F, Mosekilde L. Bone phosphorus/hydroxyproline ratio and bone histomorphometry in normals. Scand J Clin Lab Invest 1978; 38: 89-91.

14 Christiansen C, Rødbro P, Jensen H. Bone mineral content in the forearm measured by photon absorptiometry. Principles and reliability. Scand J Clin Lab Invest 1975; 35: 323-30.

15 Cohn SH, Ellis KJ, Wallach S, Zanzi I, Atkins HL, Aloia JF. Absolute and relative deficit in total-skeletal calcium and radial bone mineral in osteoporosis. $J$ Nucl Med 1974; 15: 428-35.

16 Christiansen C. Bone mineral content in epileptic patients on anticonvulsant therapy. Thesis. Dansk Undervisningsforlag, 1976.

17 Rickers H, Nielsen AH, Pedersen RS, Rødbro P. Bone mineral loss during maintenance hemodialysis. Acta Med Scand 1978; 204: 263-7.

18 Nielsen HE, Mosekilde Le, Mosekilde Li, Melsen B, Christensen P, Olson KJ, Melsen F. Relation of bone mineral content, ash-weight and bone mass: implications for correction of bone mineral content for bone size. Clin Orthop 1980; 153: 241-7. 